\title{
Contingency Factors and Accounting Information System Design in Jordanian Companies
}

\author{
Mahmoud Al-Eqab ${ }^{1}$ and Noor Azizi Ismail ${ }^{2}$ \\ ${ }^{1}$ Prince Sultan University, Riyadh, Kingdome of Saudi Arabia \\ ${ }^{2}$ Universiti Utara Malaysia, Sintok, Kedah, Malaysia
}

\begin{abstract}
This paper examines the relationship between three contingency factors and the sophistication of AIS design. Questionnaires were distributed to 220 companies listed on Amman Stock Exchange, Jordan. The results reveal significant and positive relationships between four dimensions of IT sophistication and AIS design, and between two dimensions of business strategies and AIS design. However, no significant relationship was found between environmental conditions and the sophistication of AIS design. Interestingly, findings from this study reveal managerial IT sophistication, informational IT sophistication and functional IT sophistication are more important than technological sophistication in influencing AIS design. On the other hand, cost leadership strategy was found to be more important than innovation differentiation strategy in influencing AIS design. Overall, cost leadership strategy appears to be the most important factor that influences the sophistication of AIS design. Findings from this study imply that the sophistication of AIS design can be achieved by investing not only in the technological aspect of IT implementation but more importantly its managerial, informational and functional sophistication. Findings from this study have deepened current understanding of AIS design and its influence factors, and provided useful insights into the sophistication of IT development in Jordan. More importantly, it opens up possibilities for further studies of AIS in Jordan and other Middle East countries, and on a global basis.
\end{abstract}

Keywords: Contingency factors, information technology sophistication, environmental conditions, accounting information system

\section{Introduction}

It is widely acknowledged that the accounting profession is an important facet of our society. Worldwide, leaders of professional accounting bodies believe that a strong accounting profession plays a key role in economic development both globally and nationally. Developments in the areas of accounting, information technology (IT) and IS over the last three decades have widened the scope and roles of AIS, which is an important component of modern information system (IS). For example, the introduction of new accounting model such as ResourcesEvents-Agents (REA) and the emergence of new technology such as relational and objectoriented database have transformed the way business people view AIS (Ismail and King, 2005). The REA accounting model which is based on economic changes rather than debits and credits as in traditional accounting model has made it possible for modern AIS to capture not only historical and financial-related data but also non-financial and future-oriented data (Mauldin and Ruchala, 1999). Business people including accountants can now view accounting in a

Copyright (C) 2011 Mahmoud Al-Eqab and Noor Azizi Ismail. This is an open access article distributed under the Creative Commons Attribution License unported 3.0, which permits unrestricted use, distribution, and reproduction in any medium, provided that original work is properly cited. Contact author: Mahmoud Al-Eqab, e-mail: aleqab740@yahoo.com 
much broader perspective with added emphasis on the economies of business operations and strategic management (Ismail and King, 2005).

Traditionally, AIS tended to mirror historically developed manual accounting processes (Ismail and King, 2005). Therefore, traditional AIS were unable to adapt to change, to support critical business processes and models, and to satisfy users' information requirements, which are constantly changing over time. Modern AIS, however, can generate various types of information including accounting and nonaccounting information to assist management manages short-term problems and integrates operational considerations within long-term strategic plans (Mitchell et al, 2000). Reviews of both accounting and IS literature indicate that IT-related issues have long received the attention of both accounting and IS researchers. IT-related researches have evolved over the last three decades from IT adoption and IT sophistication issues to IT alignment and IT value delivery issues. One of the main issues with respect to IT is the impact of IT on organization (Shin, 2001) especially, its performance. For example, many scholars have begun to speculate that employees' underutilization of such modern IS may result in the failure to gain the expected success of such implementations and hence, threatens the long-term viability of such systems (Jasperson et al, 2005).

Following this, many IT researchers have attempted to explain the benefits IT will bring to the organization. Several studies that have adopted the contingency approach have suggested that IT needs to be aligned with other contingent factors to have a real impact on organization. The alignments between contingency factors such as business strategy, organizational structure, and strategic IT management have been found to have significant impacts on organizational performance (Chang, 2001). Another issue with respect to IT is the difficulty in comparing the results of previous studies. Firstly, IT researchers have used different measures of IT sophistication. Most ITrelated studies also focused on the technological dimension IT sophistication while neglecting other IT dimensions such as informational, functional and managerial sophistication (Ismail and King, 2007). Recognizing the importance of IT to business and accounting, accounting researchers have also investigated several IT-related issues. While early AIS studies focused on the impact of general IT on accounting and the roles of accountants, more recent AIS studies focused on the impact of more sophisticated IS such as ERP on the role of accountants (Rom and Rohde, 2006). However, as suggested by Hunton (2002), most of AIS studies are very descriptive in nature and therefore, fail to reveal in a meaningful way the relationship between IT and AIS and its impact on organizational performance.

Reviews of AIS literature also indicate that most AIS studies have incorporated contingency factors such as organizational structure, business strategy, and environmental condition in their research model but have neglected the influence of IT on AIS design. Furthermore, the few studies that have examined the relationship between AIS design and IT have defined IT in a narrow perspective (Ismail, 2004). Similar to IT researches, these studies viewed IT from the technological perspective only but failed to incorporate other perspectives of IT sophistication such as informational, functional and managerial. Hunton and Flowers (1997) suggested that a more comprehensive AIS study is needed to explain the relationship between IT and accounting and its subsequent impact on organization in general and accounting/accountants in particular. Furthermore, most of previous IT/AIS studies were conducted in developed countries (Ismail and King, 2005). Very few of such studies have been carried out in developing countries especially in the Middle East. 
Due to the continuous flow of considerable amount of empirical studies which investigate the contingency factors and accounting and/or IS and indicates the importance and vitality of this theory, this study is theoretically and empirically constituted upon contingency theory which has long been applied in both accounting and information system disciplines (Chenhall, 2003). The contingency theory suggests that an organization's structure is based on contextual factors such as environmental conditions, business strategy, organizational structure, production technology, and management style (Ismail and King, 2004).

The above discussions relating to the evolution of IT and its subsequent impact on accounting profession have raised several interesting issues that need to be carefully addressed, particularly among developing countries like Jordan. Jordan, unlike other Middle East countries, is a small country with very limited natural resources. IT development in Jordan is also underdeveloped compared to developed countries and even some developing countries
(Murrar, 2003). Despite this, the Jordanian government with the strong support from the King of Jordan has recently invested quite heavily in IT development with the hope to be a leader among the Arab countries (Nasereddin, 2006). Therefore, a comprehensive AIS study which incorporates both IT and accounting issues could contribute to further understanding of the IT-related issues such as the combined effect of contingency factors including IT on AIS design, not only in Jordan but also other developing countries.

Findings from this study could explain not only the sophistication of IT adoption among Jordanian companies but also the influence of other contingency factors on the AIS design of adopting companies. This is important as even though AIS users could now generate and use accounting information in a more strategic way, lack of understanding of available technology and contemporary accounting information that could be generated by the technology would hamper the benefits of IT implementation.

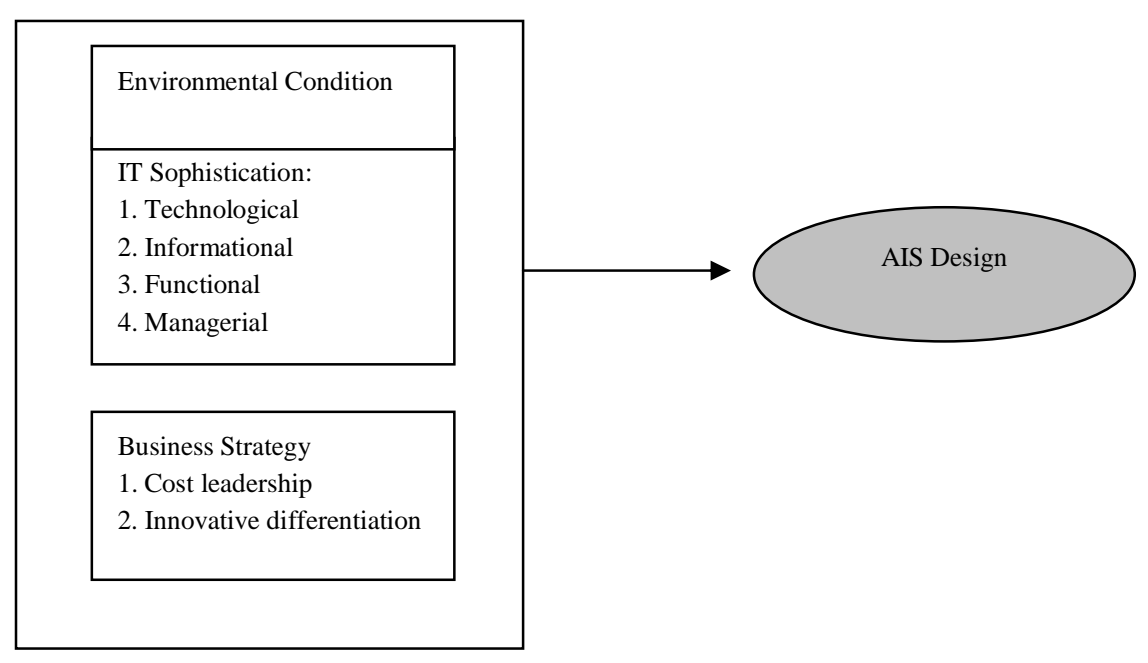

Figure 1: Research Model 


\section{Research Model}

The above discussions highlight several important issues relating to accounting and IS from the perspective of contingency theory. The first issue relates to the lack of a comprehensive empirical study that examines the relationship between IT and AIS especially among Middle East countries. The second issue relates to the inconsistency in the measurement of IT sophistication. Therefore, further study is needed to better explain the relationship between contingency factors especially IT sophistication and AIS design. This study represents the first attempt to fill in the gap in the specific context of Middle East countries. An outline research model for the relationship between three contextual factors and IT sophistication on AIS design is illustrated in Figure 1 above, and followed by discussions on hypothesis development:

\section{Hypotheses Development}

\section{IT Sophistication and AIS Design}

IT is one of the mechanisms that can be used to increase organizational information processing capabilities (El Louadi, 1998). Huber (1990, p. 65) argued that "use of advanced IT leads to more available and more quickly retrieved information, including external information, internal information, and previously encountered information, and thus leads to increased information accessibility". Daft and Lengel (1986) also placed particular emphasis on IT as a means by which organizations reduce uncertainty. El Louadi (1998) confirmed that organizational IT sophistication has a direct effect on the amount of external and internal information provided. More recently, Ismail and King (2007) found a significant relationship between IT sophistication and AIS alignment. Therefore, it is expected that firms with more sophisticated IT are more likely to have more sophisticated AIS design than those that are not. Since IT sophistication is a multidimensional variable as suggested by Raymond and Pare (1992), the general hypothesis above is divided into four sub-hypotheses relating each of four dimensions of IT sophistication to AIS design.

\section{- Technological Sophistication and AIS Design}

The technological dimension of IT sophistication has been used in the literature in various ways such as variety of IT used, hardware characteristics, development tools, man-machine interface, processing mode, and type of operation (Raymond and Pare, 1992). However, very few studies have investigated the specific relationship between technological sophistication and AIS design. Since it is a core assumption in accounting research that sophisticated technologies will provide a sufficient quantity of information for accountants, it follows that such information can be used when designing AIS so that more relevant information can be supplied to managers (Boulianne, 2007). For example, when companies have different types of technologies such as Enterprise Resources Planning (ERP), Supply Chain Management (SCM) and Customer Relationship Management (CRM), AIS will be designed by taking into consideration these technologies at hand to achieve enhanced information that will be relevant to end users which will lead to better organizational effectiveness (Doms et al, 2004). Therefore, it is expected that companies with more sophisticated technologies will have more sophistication in AIS design. Thus, the hypothesis can be stated as follow:

$\mathbf{H}^{\mathbf{1}}$ : There is a positive relationship between technological sophistication and the sophistication of AIS design among Jordanian listed companies.

\section{- Informational Sophistication and AIS Design}

Informational dimension of IT sophistication refers to the type of applications portfolio 
and integration of these applications (Raymond and Pare, 1992). Targowski and Tarn (2007) concluded that the benefits of the IS implementation has something to do with a concept of the application portfolio. Use of advanced applications such as order entry, budget variances, production variances, budgeting, production planning and control, and activity-based accounting leads to more available and more quickly retrieved information. Hence, it is expected that firms with more sophisticated informational applications will have a higher degree of AIS design, which leads to the following hypothesis:

$\mathbf{H}^{2}$ : There is a positive relationship between informational sophistication and the sophistication of AIS design among Jordanian listed companies.

\section{- Functional Sophistication and AIS Design}

Researchers have used various dimensions such as decisional level and user participation to represent functional sophistication (Raymond and Pare, 1992). Choe (1996) found a significant positive relationship between user participation and AIS design. User participation in IS development such as participation in programming, participation in system maintenance and problem solving, elaboration of development schedule, elaboration of development budget, and training of new users on available system can help in the design of AIS by providing ways on how to improve and produce accounting systems that can avoid incorrect administrative transactions. Eventually, user participation can improve the performance of system design quality by aligning the system to fit the various needs of the organization. Zeffane et al (1998) also stated that the degree of user participation was found to have a significant effect upon the quality of data such as accuracy, timeliness, and completeness of data. With the advent of modern technologies, the role of accountant has shifted from number crunching to business advisor. Due to the nature of their work, Elliot (1992) argued that accountants understand the business process better than others. Therefore, accountants' active participation in the IS implementation would contribute to better or more sophisticated AIS implementation because they will be able to provide significant inputs and suggestions to the AIS design to the advantage of the organizational performance. Hence, the hypothesis can be stated as follows:

$\mathbf{H}^{3}$ : There is a positive relationship between functional sophistication and the sophistication of AIS design among Jordanian listed companies.

\section{- Managerial Sophistication and AIS Design}

The term managerial sophistication has been employed in the literature in various ways such as top management support, IT investment, IT adoption process, control of IT, and evaluation of IT (Raymond and Pare, 1992). The most dominant dimension found to have implication on IT implementation was top management commitment. Considering the amount of resources such as financial and human effort invested in IT project among large businesses, commitment from top management is crucial to ensure successful IT implementation such as AIS. In addition, top management can determine the success or failure of computerization projects because they play a dominant role in IS planning especially, financial resource planning (Lin et al, 2007). In the context of AIS, top management with IT knowledge are in a better position than those without this knowledge, because they can understand the company's AIS design and then use their knowledge in IS development planning to match the company's information needs. Therefore, it is expected that in companies where the top management highly participate in IS development and planning more sophistication in AIS design will be accomplished. Hence, the hypothesis can be stated as follow: 
$\mathbf{H}^{\mathbf{4}}$ : There is a positive relationship between managerial sophistication and the sophistication of AIS design among Jordanian listed companies.

\section{Environmental Condition and AIS Design}

Gordon and Miller (1976, p. 60) hypothesized that "...as environmental dynamism increases, organizations would require more non-financial accounting information on matters such as competitors actions and consumer tastes, increase the frequency of reporting and make greater use of forecasted information". Chong and Chong (1997) reemphasized the importance of external, nonfinancial and future-oriented data in a turbulent and uncertain environment. It is through the management of external information that businesses will be able to reduce the uncertainty that they perceive in their environment. For example, broad scope, timely and frequent, aggregated and integrated accounting information would be particularly useful for managers to respond rapidly to changes in the competitive environment and market demand. However, Mia (1993) warned that sophisticated accounting information is only effective in terms of performance when the level of environmental uncertainty is high. When uncertainty of the environment is low, management is able to make relatively accurate predictions about the market, thus requires less sophisticated information. Therefore, it is expected that firms that operate in a more turbulent and uncertain environment are more likely to have more sophisticated AIS design than those that are not, hence the following hypothesis:

$\mathbf{H}^{5}$ : There is a positive relationship between perceived environmental uncertainty and the sophistication of AIS design among Jordanian listed companies.

\section{Business Strategy and AIS Design}

Chong and Chong (1997) suggested that business strategy would determine its environmental domain, which in turn influence the scope of accounting information required to deal with the uncertainty. Chenhall (2003) suggested that strategy differs from other contingency variables because it is not an element of content but rather the means whereby managers can influence the nature of the external environment, and the technologies of the organization. Otley (1980) suggested that business strategy is the important factor that influences the main characteristics of AIS design. Furthermore, early researchers like Miles and Snow (1978) and Porter (1980) proposed that AIS design is used differently depending on the organization's strategy. Simons (1990) found evidence that organizations with appropriate strategies employ AIS in successful ways. Theoretically, companies employ certain business strategies to improve their business performance (Fisher et al., 2005). To effectively plan and implement business strategy, firms need updated and resourceful business information. One of the ways to do this is through the design of AIS (Ismail and King, 2007). The better and more sophisticated the AIS design is, the better the performance of companies. Since business strategy is a multidimensional variable as suggested by Paopun (2000), the hypothesis is divided into two sub-hypotheses relating to each of two dimensions of business strategy as the follow.

\section{- Cost Leadership and AIS Design}

Cost leadership is one of the important strategies adopted by previous contingency studies. Chang (2001) concluded that when a company pursues a cost leadership strategy, it would require a higher degree of aggregation information to improve operational procedure. In other words, cost leadership strategy aims to reduce costs through the whole business process from manufacturing to the final stage of selling the product. Any processes that do not contribute towards minimization of cost base should be outsourced. Low costs will permit a firm to sell relatively standardized products accepted by customers at the lowest price to 
gain competitive advantage and increase market share (Husted and Allen, 2006). That means the cost efficiency gained in the whole process will enable a firm to mark up a price lower than competitors for longer time which ultimately could not match such a low cost base. These competitive advantages gained by adopting cost leadership strategy lead us to know what is the features acceptable is to many customers and in turn put these features into IT team regards avoid the variances in next business process. However, costing information needed by managers to make effective decisions rely on the sophistication of AIS design (Bolon, 1998). Therefore, this study proposed the following:

$\mathbf{H}^{6}$ : There is a positive relationship between cost leadership strategy and the sophistication of AIS design among Jordanian listed companies.

\section{- Innovative Differentiation and AIS Design}

Innovative differentiation strategy is another widely used strategy by previous contingency studies. This strategy aims to emphasize the uniqueness of a product as perceived by the customers. In other words, the strategy is aimed at the broad market that involves the creation of a product/service perceived throughout its industry as unique. The company or business unit may then charge a premium for its product. Differentiation is a viable strategy for earning above average returns in a specific business because the resulting brand loyalty lowers customers' sensitivity to price. Increased costs can usually be passed on to the buyers. Kim and Mauborgne (2004) suggested that a differentiation strategy is more likely to generate higher performance because differentiation creates a better entry barrier. However, similar to cost leadership strategy, the innovation differentiation strategy can only be effectively planned and implemented via sophisticated AIS design. Only sophisticated AIS can supply information to help managers make effective decisions relating to the strategy (Bolon, 1998). Therefore, this study proposed the following hypothesis:

$\mathbf{H}^{7}$ : There is a positive relationship between innovative differentiation strategy and the sophistication of AIS design among Jordanian listed companies.

\section{Research Methodology}

The focus of this study was the relationship between contingency factor and AIS design. To achieve this, a mail questionnaire survey was carried out to gather the data. As at $30^{\text {th }}$ June 2008, Amman Stock Exchange (ASE) provides a total of 260 addresses of listed companies. Forty addresses were used for the pre-test and pilot test, and the remaining 220 were used for the main survey. The questionnaire was refined in three stages: pre-testing with academics and research students, pre-testing with companies' accountants, and pilot testing with companies' accountants. The pre-test aimed to clarify the wording of both the questionnaire instructions and questions, whilst the pilot test attempted to examine patterns of respondents' answers and thus their understanding of the questionnaire. The questionnaires were addressed to the accountants of the companies. Accountants were chosen to be the respondents of this study because they were more likely to have valid perceptions of the AIS design adopted by the companies.

\section{Measurement of Variables}

There are four main variables used in this study. The measurements of the constructs were adopted from previous studies. For example, the measurement of IT sophistication constructs are based mainly on Ismail and King (2004), who validated an instrument originally developed by Raymond and Pare (1992). The measure of strategic choice, on the other hand, is adapted from Paopun (2000), which focused on two business strategies, cost leadership and innovative differentiation. Questions for 
measuring perceived environmental uncertainty were adopted from Khandwalla (1977), who operationalized it in terms of the degree of change and unpredictability in the firm's markets, competitors, and production technology. Finally, questions for AIS design are based on original instrument developed by Chenhall and Morris (1986) and validated by Ismail and King (2005).
They classified AIS design into four dimensions, namely; scope, aggregation, integration, and timeliness. With the exception of technological IT sophistication and information IT sophistication which were measured using nominal questions, other constructs were measured using a fivepoint likert scale. The results of Cronbach Alpha test are shown in Table 1 below.

Table 1: Reliability Analysis

\begin{tabular}{ll}
\hline Factors & Cronbach Alfa \\
\hline Functional Sophistication & .806 \\
Managerial Sophistication & .845 \\
Cost leadership strategy & .795 \\
Environmental Conditions & .800 \\
AIS design & .751 \\
IT benefits & .803 \\
\hline
\end{tabular}

\section{Results}

\section{Descriptive Statistics}

The survey questionnaires were mailed to 220 companies in August 2008. A total of 180 companies responded to the survey after a period of two months and two follow-up reminders, resulting in about 82 percent response rate. Results in Table 2 show that about $43 \%$ of the companies are in the financial sector, $24 \%$ in the service sector and $33 \%$ in the industrial sector. Table 3 provides the age categorization of the responding companies. About $70 \%$ of the companies were established more than 10 years, and can be considered as matured companies. This study used the number of years using computer-based system to determine the level of IT experience acquired. The results in Table 4 show that about $79 \%$ of the companies have used IT for at least 5 years. It is observed that more than one-third of respondent companies (38.9\%) have been using computer-based systems between 5 and 10 years, and a small percentage $(3.3 \%)$ for more than 20 years. Almost one-fifth of respondent companies (21.1\%) have been using computer-based systems less than five years. The result suggests that the majority of the Jordanian companies in the sample have considerable experience with computer-based systems.

Table 2: Industry Type

\begin{tabular}{lll}
\hline Industry type & Frequency & Percentage \\
\hline Financial Sector & 77 & 42.8 \\
Services Sector & 43 & 23.9 \\
Industrial Sector & 60 & 33.3 \\
Total & $\mathbf{1 8 0}$ & $\mathbf{1 0 0 . 0}$ \\
\hline
\end{tabular}


Table 3: Company Age

\begin{tabular}{lll}
\hline Company Age & Frequency & Percentage \\
\hline 10 years or less & 52 & 28.9 \\
11 - 20 years & 68 & 37.8 \\
$21-$ 30 years & 36 & 20.0 \\
31 - 40 years & 18 & 10.0 \\
More than 40 years & 6 & 3.3 \\
Total & $\mathbf{1 8 0}$ & $\mathbf{1 0 0 . 0}$ \\
\hline
\end{tabular}

Table 4: Number of Years Using Computer-based Systems

\begin{tabular}{lll}
\hline Number of years using computers & Frequency & Percentage \\
\hline Less than 5 years & 38 & 21.1 \\
5 - 10 years & 70 & 38.9 \\
11 - 15 years & 48 & 26.7 \\
16 - 20 years & 18 & 10.0 \\
More than 20 years & 6 & 3.3 \\
Total & $\mathbf{1 8 0}$ & $\mathbf{1 0 0 . 0}$ \\
\hline
\end{tabular}

\section{Hypotheses Testing}

Multiple regression analysis was conducted to analyze the relationships between contingency factors and the sophistication of AIS design. Validity tests such as content validity, construct validity, and criterion validity for all variables and reliability were first conducted in order to examine the goodness of data. The assumptions of linearity, normality, and homogeneity of data were also tested and the obtained results show that the assumptions of linearity, normality, and homoscedasticity of data were met.

To test the hypotheses, the research model is represented by the following regression equation:
$\mathrm{X}_{8}=\mathrm{P}_{81} \mathrm{X}_{1}+\mathrm{P}_{82} \mathrm{X}_{2}+\mathrm{P}_{83} \mathrm{X}_{3}+\mathrm{P}_{84} \mathrm{X}_{4}+\mathrm{P}_{85} \mathrm{X}_{5}+$ $\mathrm{P}_{86} \mathrm{X}_{6}+\mathrm{P}_{87} \mathrm{X}_{7}+\mathrm{P}_{8 \mathrm{a}} \mathrm{R}_{\mathrm{a}}$

Where:

$\mathrm{X}_{8}=$ AIS design; $\mathrm{X}_{1}=$ technological; $\mathrm{X}_{2}=$ informational; $\mathrm{X}_{3}=$ functional; $\mathrm{X}_{4}=$ managerial; $X_{5}=$ cost leadership; $X_{6}=$ innovative differentiation; $\mathrm{X}_{7}=$ environmental conditions.

The regression equation treated AIS design $\left(\mathrm{X}_{8}\right)$ as the dependent variable and technological IT sophistication $\left(\mathrm{X}_{1}\right)$, informational IT sophistication $\left(X_{2}\right)$, functional IT sophistication $\left(\mathrm{X}_{3}\right)$, managerial IT sophistication $\left(X_{4}\right)$, cost leadership $\left(X_{5}\right)$, innovative differentiation $\left(\mathrm{X}_{6}\right)$, and environmental conditions $\left(\mathrm{X}_{7}\right)$ as the independent variables. 
Table 5: Regression of $X_{8}$ Against $X_{1}, X_{2}, X_{3}, X_{4}, X_{5}, X_{6}$ and $X_{7}$

\begin{tabular}{|l|l|l|l|l|}
\hline & Variables & $\begin{array}{l}\text { Regression } \\
\text { coefficient }\end{array}$ & T value & Significance \\
\hline $\mathrm{X}_{1}$ & Technological & .444 & 2.235 & $.027^{*}$ \\
\hline $\mathrm{X}_{2}$ & Informational & .843 & 3.819 & $.000^{*}$ \\
\hline $\mathrm{X}_{3}$ & Functional & .147 & 2.942 & $.004^{*}$ \\
\hline $\mathrm{X}_{4}$ & Managerial & .256 & 4.345 & $.000^{*}$ \\
\hline $\mathrm{X}_{5}$ & Cost leadership & .294 & 5.925 & $.000^{*}$ \\
\hline $\mathrm{X}_{6}$ & Innovative differentiation & .097 & 2.174 & $.031^{*}$ \\
\hline $\mathrm{X}_{7}$ & $\begin{array}{l}\text { Environmental } \\
\text { conditions }\end{array}$ & .078 & 1.820 & .071 \\
\hline
\end{tabular}

$$
\mathrm{R}=0.731 ; \mathrm{R}^{2}=0.855 ; \text { Adjusted } \mathrm{R}^{2}=0.720 ; \mathrm{F}=66.688 ; \mathrm{p}<0.01
$$

The results of multiple regression analysis display the correlations between the variables, the unstandardized regression coefficient (B) and intercept, the standardized regression coefficient $(\beta), \mathrm{R}, \mathrm{R}^{2}$ and adjusted $\mathrm{R}^{2}$. A summary of results are shown in Table 5 . The multiple $\mathrm{R}$ under consideration is $0.731\left(\mathrm{R}^{2}=0.855\right)$. The $\mathrm{F}$ value of 66.688 which is significant at the 0.01 level suggests that it is extremely improbable that $\mathrm{R}$ in the population is zero. While the $F$ ratio is useful as a test of statistical significance for the equation as a whole, a $\mathrm{t}$ value for each coefficient and an associated two-tailed significant test represents a test of the statistical significance of the individual regression coefficients. The outputs in Table 4 shows that technological IT sophistication $\left(\beta_{1}=0.444 ; \mathrm{p}<0.05\right)$, informational IT sophistication $\left(\beta_{2}=0.843\right.$; $\mathrm{p}<0.01)$, functional IT sophistication $\left(\beta_{3}=\right.$ $0.147 ; \mathrm{p}<0.01)$, managerial IT sophistication $\left(\beta_{4}=0.256 ; \mathrm{p}<0.01\right)$, cost leadership $\left(\beta_{5}=\right.$ 0.294; $\quad \mathrm{p}<0.01$ ), and innovative differentiation $\left(\beta_{4}=0.097 ; \quad \mathrm{p}<0.05\right)$ contribute significantly to regression with $\mathrm{t}$ value of 2.235, 3.819, 2.942, 4.345, 5.925 and 2.174 respectively, thus providing support for $\mathrm{H}^{1}, \mathrm{H}^{2}, \mathrm{H}^{3}, \mathrm{H}^{4}, \mathrm{H}^{5}$ and $\mathrm{H}^{6}$. Environmental conditions however appear unimportant.

\section{Discussions and Conclusions}

The objective of this study is to examine the factors that influence AIS design in the specific context of Jordanian listed companies. Six factors, technological IT sophistication, informational IT sophistication, functional IT sophistication, managerial IT sophistication, cost leadership and innovative differentiation, are found to significantly influence AIS design. More interestingly, findings from this study reveal that managerial IT sophistication, informational IT sophistication and functional IT sophistication are more important than technological sophistication in influencing AIS design. Furthermore, cost leadership strategy was found to be more important than innovation differentiation strategy in influencing AIS design. Overall, cost leadership strategy appears to be the most important factor that influences the sophistication of AIS design, followed by, in descending order of importance, managerial IT sophistication, informational IT sophistication, functional IT sophistication, technological IT sophistication, and innovative differentiation strategy. This study, however, found no significant relationship between environmental

conditions and the sophistication of AIS design. Probably, the sophistication of technology adopted by Jordanian companies has enabled them to generate sufficient information irrespective of the conditions of the environment.

There are two important implications from the findings of this study. First, companies 
should give priority to its information needs prior to investing in any IS project. Other aspects such as functional and managerial are also important in addition to technological sophistication. Second, companies should be cost cautious in making IT decision. Investing heavily on the expensive technological sophistication would be a big waste if companies neglect other aspects like informational, functional and managerial. In summary, this study has deepened current understanding of AIS design and its influence factors, and has provided useful insights into the sophistication of IT development in Jordan. More importantly, it opens up possibilities for further studies of AIS in Jordan and other Middle East countries, and on a global basis.

\section{References}

Bolon, D. S. (1998). "Information Processing Theory: Implications for Health Care Organizations," International Journal of Technology Management, 15, 211-221.

Boulianne, E. (2007). "Revisiting Fit between AIS Design and Performance with the Analyzer Strategic-type," International Journal of Accounting Information Systems, 8, 1-16.

Chang, Y. W. (2001). "The Effects of Environment, Strategy and Organizational Characteristics on the Performance of Accounting Information Systems," Unpublished $\mathrm{PhD}$ thesis, University of Chicago.

Chenhall, R. H. (2003). "Management Control Systems Design within its Organizational Context: Findings from Contingency Based Research and Directions for the Future," Accounting, Organizations and Society, 28, 127-168.

Chenhall, R. H. \& Morris, D. (1986), "The Impact of Structure, Environment, and Interdependence on the Perceived Usefulness of Management Accounting Systems," The Accounting Review, 61(1), 1635.
Choe, J. M. (1996). "The Relationships among Performance of Accounting Information Systems, Influence Factors, and Eevolution Level of Information Systems," Journal of Management Information Systems, 12(4), 215-239.

Chong, V. K. \& Chong, K. M. (1997). "Strategic Choices, Environmental Uncertainty and SBU Performance: a Note on the Intervening Role of Management Accounting Systems," Accounting and Business Research, 27(4), 268-276.

Daft, R. L. \& Lengel, R. H. (1986). "Organization Information Requirements, Media Richness and Structural Design," Management Science, 32(5), 554-571.

Doms, M. E., Jarmin, R. S. \& Klimek, S. D. (2004). "Information Technology Investment and Firm Performance in U.S. Retail Trade," Economics of Innovation and New Technology, 13(7), 595-613.

Elliot, R. K. (1992). "The Third Wave Breaks on the Shores of Accounting," Accounting Horizons, 6(2), 61-85.

El Louadi, M. (1998). "The Relationship among Organization Structure, Information Technology and Information Processing in Small Canadian Firms," Canadian Journal of Administrative Sciences, 15(2), 180-199.

Fisher, D. K., Kent, R., Nottingham, L. \& Field, J. R. B. (2005). "Characteristics of Effective Leaders in Economic Development: An Exploratory Study," Southern Business Review, 31(1), 13-27.

Gordon, L. A. \& Miller, D. (1976). "A Contingency Framework for the Design of Accounting Information Systems," Accounting, Organizations and Society, 1(1), 59-69.

Huber, G. P. (1990). "A Theory of the Effects of Advanced Information Technologies on Organizational Design, Intelligence, and Decision Making," Academy of Management Review, 15(1), 47-71. 
Hunton, J. E. (2002). "Blending Information and Communication Technology with Accounting Research," Accounting Horizons, 16(1), 55-67.

Hunton, J. E. \& Flowers, L. (1997). 'Information Technology in Accounting: Assessing the Impact on Accountants and Organizations,' Advances in Accounting Information Systems, 5, 3-34.

Husted, B. W. \& Allen, D. B. (2006), "Corporate Social Responsibility in the Multinational Enterprise: Strategic and Institutional Approaches," Journal of International Business Studies, 37 (6), 838849.

Ismail, N. A. (2004), "AIS Alignment and Firm Performance in SMEs,' Unpublished PhD thesis, Loughborough University, UK.

Ismail, N. A. \& King, M. (2005). "Firm Performance and AIS Alignment in Malaysian SMEs," International Journal of Accounting Information Systems, 6(4), 241-259.

Ismail, N. A. \& King, M. (2007). "Factors Influencing the Alignment of Accounting Information Systems in Small and Medium Sized Malaysian Manufacturing Firms," Journal of Information Systems and Small Business, 1(1/2), 1-19.

Jasperson, J. S., Carter, P. E. \& Zmud, R. W. (2005). 'A Comprehensive Conceptualization of the Post-adoptive Behaviours Associated with IT-enabled Work Systems, ${ }^{\prime}$ MIS Quarterly, 29(3), 525-557.

Khandwalla, P. N. (1977). The Design of Organizations, New York: Harcourt Brace Jovanovich, Inc.

Kim, E. \& Lee, J. (1986). "An Exploratory Contingency Model of User Participation and MIS Use," Information and Management, 11(2), 87-97.
Kim, W. C. \& Mauborgne, R. (2004). "Blue Ocean Strategy," Harvard Business Review, October, 76-84.

Lehman, J. A. (1986), "Organizational Size and Information System Sophistication," Journal of Management Information Systems, 3(2), 78-86.

Lin, C., Huang, Y., Cheng, M. \& Lin, W. (2007). 'Effects of Information Technology Maturity on the Adoption of Investment Evaluation Methodologies: A Survey of Large Australian Organizations,' International Journal of Management, 24(4), 697-711.

Mahmood, M. A. \& Mann, G. J. (2000). "Special Issue: Impacts of Information Technology Investment on Organizational Performance," Journal of Management Information Systems, 16(4), 3-10.

Mauldin, E. G. \& Ruchala, L. V. (1999). "Towards a Meta-theory of Accounting Information Systems," Accounting, Organizations and Society, 24, 317-331.

Mia, L. (1993). "The Role of MAS Information in Organizations: An Empirical Study," British Accounting Review, 25, 269-285.

Miles, R. E., Snow, C. C., Meyer, A.D. \& Coleman, H. J. Jr (1978). Organizational Strategy, Structure and Process, New York: McGraw Hill.

Mitchell, F., Reid, G. \& Smith, J. (2000). 'Information System Development in the Small Firm: The Use of Management Accounting,' CIMA Publishing.

Murrar, R. A. (2003). 'Information Technology in the Hashemite Kingdom of Jordan,' [Online] [Retrieved February 15, 2008],

http://www.american.edu/initeb/ra9847a/j ordan.htm 
Nasereddin, M. (2006). 'The Fourth Forum Communications and Information Technology, Jordan, Dead Sea, Queen Rania Official Website,' [Online] [Retrieved December 15, 2007], http://www.queenrania.jo/contentArabic/m odulePopup.aspx?secID=anditemID=1332 an dModuleID=pressand ModuleOrigID=news

Otley, D. T. (1980). "The Contingency Theory of Management Accounting: Achievement and Prognosis," Accounting, Organizations and Society, 5(4), 413-428.

Paopun, V. (2000). 'A Study of the Relationship between Investment in Information Technology and Organizational Performance in the Retail Industry,' Unpublished PhD thesis, Nova Southeastern University.

Porter, M. E. (1980). Competitive Strategy, New York: The Free Press.

Raymond, L. \& Pare, G. (1992). Measurement of Information Technology Sophistication in Small Manufacturing Businesses, Information Resources Management Journal, 5(2), 4-16.
Rom, A. \& Rohde, C. (2006). "Enterprise Resource Planning Systems, Strategic Enterprise Management Systems and Management Accounting: A Danish study," Journal of Enterprise Information Management, 19(1), 50-66.

Shin, N. (2001). "The Impact of Information Technology on Financial Performance: The Importance of Strategic Choice," European Journal of Information Systems, 10, 227-236.

Simons, R. (1990). "The Role of Management Control Systems in Creating Competitive Advantage: New Perspectives," Accounting, Organization and Society, 15(1/2), 127-143.

Targowski, A. \& Tarn, J. M. (2007). Enterprise Systems Education in the 21st Century, US: Idea Group Inc (IGI).

Zeffane, R., Cheek, B. \& Meredith, P. (1998). "Does User Involvement During Information Systems Development Improve Data Quality?," Human Systems Management, 17(2), 115-121. 